\title{
無溶剤型およびハイソリッド型エポキシ 樹脂塗料について
}

\section{1.は じめに}

常温乾燥形 2 液性の溶滆型エポキシ樹脂塗料は, 今更 いらまでもなく長年にわたり船舶，化学プラント，橋 梁, 鋼管, 海洋構造物などの塗装に広く使用され，その すぐれた防蝕性能は実証されている。エポキシ樹脂を用 いた無溶剤型, およびハイッリッド型塗料についても, 早くから開発研究が行なわれ，1957〜1958 年頃「Solventless」(無溶剂型) といら用語がすでに文献上用いら れている。1960年には米国海軍が潜水艦の艦体および艦 内タンクの防蝕に無溶剤に近いハイソリッド型エポキシ 樹脂塗料を使用して，実用試験を実施した記録が残され ている。また, 1968 年に高粘度塗料の塗装用に特殊な 2 液式ホットスプレー装置が樹脂一機械メーカーにより共 同開発され, この種の無溶剤型, およびハイソリッド型 塗料の使用が一層容易になった。その後，“塗料の配合技 術面, 特に硬化剂の研究開発面で多くの進歩がみられた ものの, 叙装作業性と塗膜性能のバランス上, いくつか の難点が依然として残され，一般塗料として末端で広く 受入れられるには至っていないのが実情であるう。

無溶剤型，あるいは八イソリッド型エポキシ樹脂塗料 の当初の開発目的は, 主として, (1) 火災・爆発防止 の危険防止，（2）密閉系内での塗装工の安全確保，(3) 所要塗装回数の削減による省力化の 3 点に置かれてい た。しかし, 最近では種々の社会的な要請,すなわち産業 公害をめぐる環境規制の強化, 省資源／省エネルギー対 策などの要因を踏まえたグローバルな視点から，より沉 用性があり，乙かむ，ょり高性能の無溶剤型，および八

昭和 55.9.17 受理

Epoxy Resin based Solventless and High Solid Coatings

Toshio Sudou

* 油化シェルエポキシ株式会社 東京都千代田区霞が関 3-2-5（霞が関ビル）(干100）
須 藤 敏 雄*

イソリッド型エポキシ樹脂塗料の開発が,必要とされる情 勢にあり，塗料配合技術の見直しが迫られている。

本稿では, 常温乾燥形 2 液性の無溶剂型, およびハイ ソリッド型エポキシ樹脂塗料を中心に, 配合技術上の基 本的な問題点, 塗膜性能, タールエポキシ代替無溶剂型 配合について，さらに最近開発された酎候性エポキシ樹 脂を用いたハイソリッド型塗料配合の可能性について述 ベ，参考に供したい。

\section{2. 塗料配合上の問題}

一般に, 分子量の比較的大きな固形エポキシ樹脂を用 いた溶剤型塗料では, 塗膜の指触乾燥時間は主として 溶剤の蒸気速度によって左右されるのに対して, 低分子 量の液状エポキシ樹脂を用いる無溶剤型, ハイソリッド 型塗料の場合, 指触乾燥（ゲル化）は樹脂／硬化剂配合 系の反応速度によって決定される。無溶剂型，あるいは ハイソリッド型の 塗料配合では, 塗装作業性の 観点か ら, 低粘度 (低分子量) エポキシ樹脂の選択が必須の条 件になる。したがって，塗膜のタレ防止を目的に指触乾 燥を早めるには, 一般に薄膜状態（樹脂／硬化剤の反応 熱が被塗物, 大気中に吸収, 発散しやすく, 蓄熱効果が 期待しにくい状態）でも速硬化性の硬化剤を使用しなけ ればならない。その結果，塗料配合系の可使時間は必然 的に短かくなる。また，無溶剤型配合では，当然ながら 溶剂が使用できないため, 塗料粘度の調整が大幅に制約 されると同時に, 溶剤型塗料と比較して下記のよらなレ オロジー的性質, 造膜特性, 塗膜物性に相当の差異がみ られる。

1) 顔料混和性

2）顔料分散系の安定性

3）被㙦物への付着性, 浸透性

4）ハジキタレ，アワなどの発生

5）層間付着性, 塗重齐性

この種の問題は塗料配合設定に当たり, 常に付随して 
表-1 常温乾燥形 2 液性エポキシ樹脂塗料のタイプ

\begin{tabular}{|c|c|c|c|}
\hline 1 & エポキシ樹脂の種類 & 溶剤含有量 $(\% w t)$ & 塗装膜厚/ 1 回 $(\mu)$ \\
\hline 型 & 主に固形樹脂 & $40 \sim 60$ & $50 \sim 100$ \\
\hline 八ィビルド 型 & " & $20 \sim 30$ & $150 \sim 200$ \\
\hline ハイソリッド型 & 主に液状樹脂 & $\sim 10$ & $150 \sim 250$ \\
\hline 無 溶 凮 型 & " & 0 & $250 \sim 400$ \\
\hline
\end{tabular}

くるため，その克服には配合技術上種々の工夫が要求さ れる。

なお，参考までに常温乾燥形 2 液性のエポキシ樹脂塗 料のタイプ別分類を表-1 に示す。ただし，この区分はあ くまで概念的なもので，技術的な厳密性をもつものでは ない。

\section{1 エポキシ樹脂について}

現在, 化学構造的に見ると各種のエポキシ樹脂が市販 されているが，無溶剤型，あるいはハイソリッド型塗料 の配合に使用される最も一般的なエポキシ樹脂は, ビス フェノール Aとェピクロルヒドリンから製造される，い わゆるビスフェノール A 型エポキシ樹脂（以下ビス $\mathrm{A}$ 型 樹脂と略す）であり，その中でも；

1）未変性液状ビス $\mathrm{A}$ 型樹脂

$\left(\mathrm{WPE}^{*}=180 \sim 200\right.$, 粘度 $=70 \sim 150$ ポイズ）

2）変性ビス $\mathrm{A}$ 型樹脂

( $\mathrm{WPE}^{*}=180 \sim 210$, 粘度 $=7 \sim 20$ ポイズ)

の 2 タイプが主流である。

一般的に，エポキシ樹脂に期待し 得る最高の 塗膜性 能, 特に耐薬品性を得るためには，(1)のタイプを使用 するのが望ましい。しかし，上記のように未変性ビスA 型樹脂は粘度がかなり高く, 配合技術上および塗装作業 上種々の制約を受汀る（2）のタイプの変性ビス $\mathrm{A}$ 型 樹脂は, 主に反応性希釈剂 (2.3 項参照)を使用して低 粘度化したグレードである。この種の変性ビス $\mathrm{A}$ 型樹脂 を使用することにより，叙装作業性は大幅に向上する が, 塗膜性能の低下は避けられない。

現段階では，まだ沉用化の域にはないが，低粘度樹脂 の 1 種にビスフェノール F 型エポキシ樹脂がある。(ビ スフェノール Fとェピクロルヒドリンから製造される) このタイプの樹脂は, 固有粘度が約 30 ポイズと低く, 未変性ビス $\mathrm{A}$ 型樹脂と比較した反応性に幾分の相違が見 られるが，硬化後の塗膜性能（耐薬品性）がすぐれてい る。したがって, 今後, 無溶剤型あるいは八イソリッド 型塗料配合に有用な樹脂となろう。

\section{2 硬化剤について}

無溶剤型, あるいは八イソリッド型塗料配合における

*エポキシ当量
最大のポイントは，いかに適切な硬化剤を選択するかで ある。現在, エポキシ樹脂の硬化剂として多数の化合物 が，それぞれ使用目的に応じて使い分けられている。し かし, 無溶剂型, あるいは八イソリッド型塗料配合系に 使用可能な硬化剂は, 少なくとも常温速乾性, 低温硬化 性をもつものに限定される。したがって, 溶剤型塗料配 合系に使用されている硬化剂, たとえば，通常のポリア ミド樹脂などは硬化特性の面で不適当といえる。一般的 な硬化剂の選定基準を次に示す。

1）常温速乾性, 低温硬化性をもつこと

2）低粘度であること

3）可使時間が長いこと

4）耐薬品性，機械的特性がすぐれていること

5）保色性が良いこと

6）毒性が少ないこと

これらの特性には互いに背反する要素が含まれ, 特定 の硬化剂にすべてを求めることは不可能に近い。

現在, 無容剤型, あるいはハイソリッド型塗料配合に 使用されている硬化剂は，ポリアミン変性物が主体であ り，代表的なタイプについて述べる。

A）ケチミン化合物

保色性の比較的良好な沉用防蝕塗料配合に使用される 代表的な硬化剂である。脂肪族ポリアミンとケトンの縮 合物で, 顔料, 大気中の水分により活性ポリアミンが遊 離して, エポキシ樹脂と反応する。すなわち, 水分が介 在しない状態では, このタイプの硬化剂は, 化学的に不 活性であるため可使時間が長く, また, 粘度も低いとい ら利点がある。反応機構上, 硬化時に幾分の溶剤（ケト ン）を放出するので，このタイプを使用した配合系は正 確にはハイソリッド型である。この配合系は加温下でも 可使時間将かなり長く，1液式ホットスプレーの使用 が可能であるが, 1 回の叙装で膜厚 $150 \mu$ 以上にした場 合, 水分吸収不良 (硬化不良), 残留溶剤増加により, 良 好な塗膜性能が期待できない。

B）その他変性ポリアミン

上記ケチミン化合物以外飞使用される変性ポリアミン としては，表-2 に示したポリアミンを主成分としたタ イプが多い。これらは，いずれも塗膜欠陥，塗装性など 
表-2 代表的なポリアミン

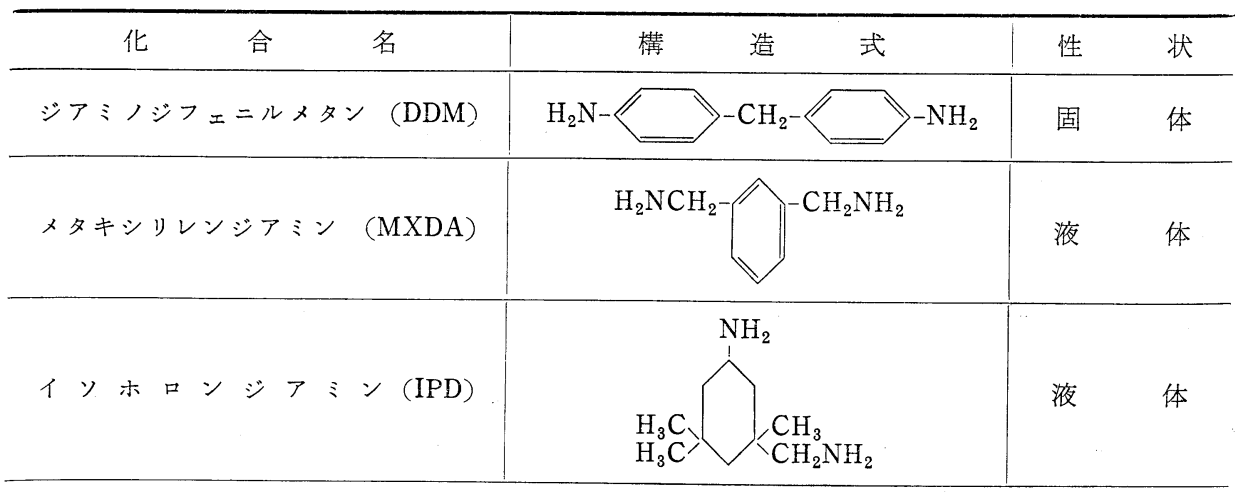

の改良をはかるため, アダクト化などの手法により変性 され，また，良好な硬化特性を付与するためにフェノ一 ル類，有機酸などが促進剤として添加されている。

i ) 変性ジアミノジフェニルメタン (DDM)

変性 DDM 系の硬化剂は耐薬品性がきわめてすぐれ ているため，重防蝕塗料配合に最適である。ただ，低 温，高温条件下に和いても良好な硬化特性を示す反面， 可使時間が短く粘度が高いので，このタイプの硬化剂を 用いた無溶剂型塗料は, 塗装作業性が悪く 2 液式ホット スプレー装置の使用が必要になる。また，このタイプに は保色性が悪いという芳香族ポリアミン系硬化剂に共通 の欠点がみられるので，塗料配合は暗色系顔料配合（赤 色酸化鉄，酸化クロムなど）に限定される。

ii）変性メタキシリレンジアミン (MXDA)

変性 MXDA 系の硬化剤を用いた配合系の塗膜は保 色性と光沢にすぐれ，上記変性 DDM 配合系には及ばな いが，相当に良好な耐薬品性をそなえている。したがっ て，防蝕と美装的要素が同時に要求されるような用途に 適した硬化剂である。変性 DDM 系の硬化剂と同様に, このタイプは粘度が高いので, 無溶剤型塗料に使用した 場合は，2液式ホットスプレー装置の使用が望ましい。

iii）変性イソホロンジアミン (IPD)

このタイプは,一般に粘度が低く, 可使時間が比較的長 いものが多い。したがって低粘度の変性ビス A 型樹脂と 組合せることにより，1液式ェアレススプレー用の無溶 剤型塗料配合に有用な硬化剂といえる。塗膜物性的には, 変色性が少なく, 変性 DDM 系硬化剂に比較し耐酸性 は劣るが, 耐アルカリ性, 耐水性はほぼ同等の性能水準 にある。

上記以外に, 脂環式ポリアミン, 複素環式アミン, メ ルカプタン系などの硬化剤が考えられるが, 無溶剤型, およびハイソリッド型塗料配合における“オールランド プレイヤー”的な硬化剤は存在しない。したがって，塗
料配合の設定意図に応じた硬化剂の選定が不可欠とな る。

\section{3 希釈剤について}

末変性ビス $\mathrm{A}$ 型樹脂を 配合した高性能の 無溶型塗料 は, 粘度がきわめて高く, 通常の 1 液式コールドスプレ 一を使用して塗装することは困難である。塗料配合系の 粘度調整，塗装作業性の改良をはかる目的で使用される のが希釈剤である。既に述べたように，この種の希釈剤 を添加して 低粘度化した変性樹脂も各種市販されてい る。

希釈剂は反応性希橎剂と非反応性希釈剂とに大別さ れ，次のよらな化合物があげられる。

1）反応性希釈剤

i ） 1 官能性エポキシ化合物

ブチル（クレジル，アルキルフェニル，高級アルュー ル）グリシジルェーテル，脂肪酸グリシジルエステルな ぞ

ii） 2 官能性エポキシ化合物

ポリプロピレン（ポリエチレン）グリコールジグリシ ジルェーテルなど

2）非反応性希釈剤

i ）低分子化合物

フタル酸ジブチル，パインオイル，フルフリルアルコ ールなど

ii ）高分子化合物

クマロンインデン系ポリマー, その他液状石油樹脂類 これらの外に低分子多官能性エポキシ化合物もある が，一般的ではない。

希釈剤は希釈効果, 硬化特性などの点でそれぞれ挙動 が異なる。塗膜性能的には, 反応性希釈剤の使用が好 ましいが，反応性希釈剤でも，一般的には配合系の反応 機能, 橋力ケ密度の低下をもたらし, その結果, 塗膜の 耐薬品性が低下するので，その使用量には限界がある。 
なお，反応性希䣋剤の中には，揮発性が高く，皮膚刺激 性が強いもの（例：ブチルグリシジルェーテル）がある ので, 使用時は労㗢衛生上の配慮を必要とする。

\section{4 顔料組成について}

無溶剤型, あるいは八イソリッド型塗料では, 相当の 厚膜塗装を 1 回で行なう場合が多い。したがって, 着色 顔料，体質顔料，その他塗膜調整剂の配合量は，溶剂型 塗料とは多少異なる。

最終塗料配合系の顔料容積濃度 (PCV) は比較的小さ く, $10 \%$ 前後に設定されるのが普通である。着色顔料の 使用量は，バインダー成分 1 重量部に対して $0.2 \sim 0.25$ 重量部の範囲であり，一般にこの配合割合で十分な隠ぺ イカが期待できる。体質顔料にはアスベスチンなどのケ 酸塩類が使用され，また，体質顔料の一部に微粉末タ ルクを併用すると, 多少のタレ防止効果が付与される。

垂直面などに厚膜塗装し，しかも，塗膜のタレを防止 するには微粉末タルクのみでは不十分で, 摇変剤の使用 が必要である。摇変剤としては, 熱安定性 (ホットスプ レー使用を想定）の良いひまし油誘導体が有効である。 普通, 摇変剂はバインダー成分に対して約 $1 \%$ (重量) 配合される。多量に使用すると, 塗膜のレベリング性が 悪化する。さらに, 平滑な塗面を得るために流れ調整剤 が必要となる。一般にシリコーン樹脂が使用されるが, この場合も塗膜性能の劣化を避けるため, 配合量は最小 限に止めるのが望ましい。

\section{3. 基本配合と塗膜特性}

\section{1 基本配合について}

前項で述べた配合上の諸点を考慮し，塗膜性能を最重 視した基本的な配合, すなわち, 未変性ビス $\mathrm{A}$ 型樹脂を 用いた 2 種の無溶剤型配合例を表-3 に示した。この基 本配合は転用性をもち, たとえば, 未変性ビス A型樹脂 を変性ビス $\mathrm{A}$ 型樹脂で代替してもよく, 少量の溶剂（キ

表-3 無溶剂型基本配合

\begin{tabular}{|c|c|c|}
\hline & 配 合 $[I]$ & 配 合 [II] \\
\hline $\begin{array}{l}\text { 未変性ビ ス A 型樹脂 } \\
(\mathrm{WPE}=180 \sim 200)\end{array}$ & $\begin{array}{l}\text { (重量部) } \\
66.0\end{array}$ & $\begin{array}{l}\text { (重量部) } \\
66.0\end{array}$ \\
\hline 酸 化 チ タン & 20.0 & - \\
\hline 赤色 酸 化 鉄 & - & 16. 2 \\
\hline ヶ イ酸 塩顔 料 & 7. 0 & 10.8 \\
\hline 徽 粉末タルタ & 5.4 & 5.4 \\
\hline 摇变 剂 & 1.5 & 1.5 \\
\hline 流 れ 調 整 牏 & 0.1 & 0.1 \\
\hline & 100.0 & 100.0 \\
\hline
\end{tabular}

シレン,ブタノールなぞ）を配合して，ハイソリッド型 の基本配合として利用することもできる。

\section{2 塗膜特性について}

基本配合（表-3）に2 種の代表的な硬化剂である变性 DDM および変性 MXDA を組合せた無溶剤型および ハイソリッド配合系の硬化塗膜に関して，2,3 の特性を 述べる。

1) 耐薬品性

未変性ビス $\mathrm{A}$ 型樹脂を配合した無溶剤型塗料の耐薬品 性は，表-4のと新りである。このデータから明らかなよ うに, 一般変性 DDM 硬化方式の方が変性 MXDA 硬化方式よりも耐薬品性が良好である。表中の評価規準 は次の通りである。

$+: 12$ カ月後も変化なし。または, わずかに損傷が見 られるが，被塗物をまだ十分に保護している。

$+0: 6$ カ月まで変化なし。その後, 部分的に損傷が見 られる。

$0: 1$ カ月まで変化なし。その後, 部分的に損傷が見ら れる。

一：耐性なし。

2) プライマー適性

無溶剤型塗料は, プライマーに対する塗装適性がよく 問題視される。PVC の異なる通常の溶剂型エポキシ系 プライマーを塗布した鋼板に，無溶剤型塗料（基本配合 [II]/变性 DDM 方式)を塗布した場合における,プ ライマーの PVC と層間付着性との相関性を示したのが 表-5である。表から，エポキシ系プライマーに無溶剤型 塗料を上塗りする場合, プライマーの PVC は小さい方 が層間付着性は大きい。

\section{3） ハイソリッド型の塗膜性能}

基本配合（表-3）に少量の溶剤を配合するとハイソリ ッド型となるが，一般に乾燥塗膜中の残留溶剤は塗膜性 能に悪影響を及ぼすことは周知の事実である。速硬化方 式をとるハイソリッド型叙料を使用して，とくに低温下 で厚膜塗装した場合, 塗膜中の溶剤残留傾向は一層強ま り，塗膜性能は著しく低下する。基本配合 $[$ II $] /$ 変性 DDM 配合系に約 $10 \%$ (重量) の混合溶剤（キンレン／ ブタノール）を配合したハイソリッド型配合系に関し て, この傾向を明白に示したのが表-6 および図-1 であ る。ハイソリッド型塗料には, 1 液式エアレススプレー 使用可能といら利点はあるが，上記のように溶剤残留を 起こしやすいため, 塗装膜厚, 塗装作業条件などの管理 に十分な配慮を要する。 
表-4 無溶剤型塗料の耐薬品性

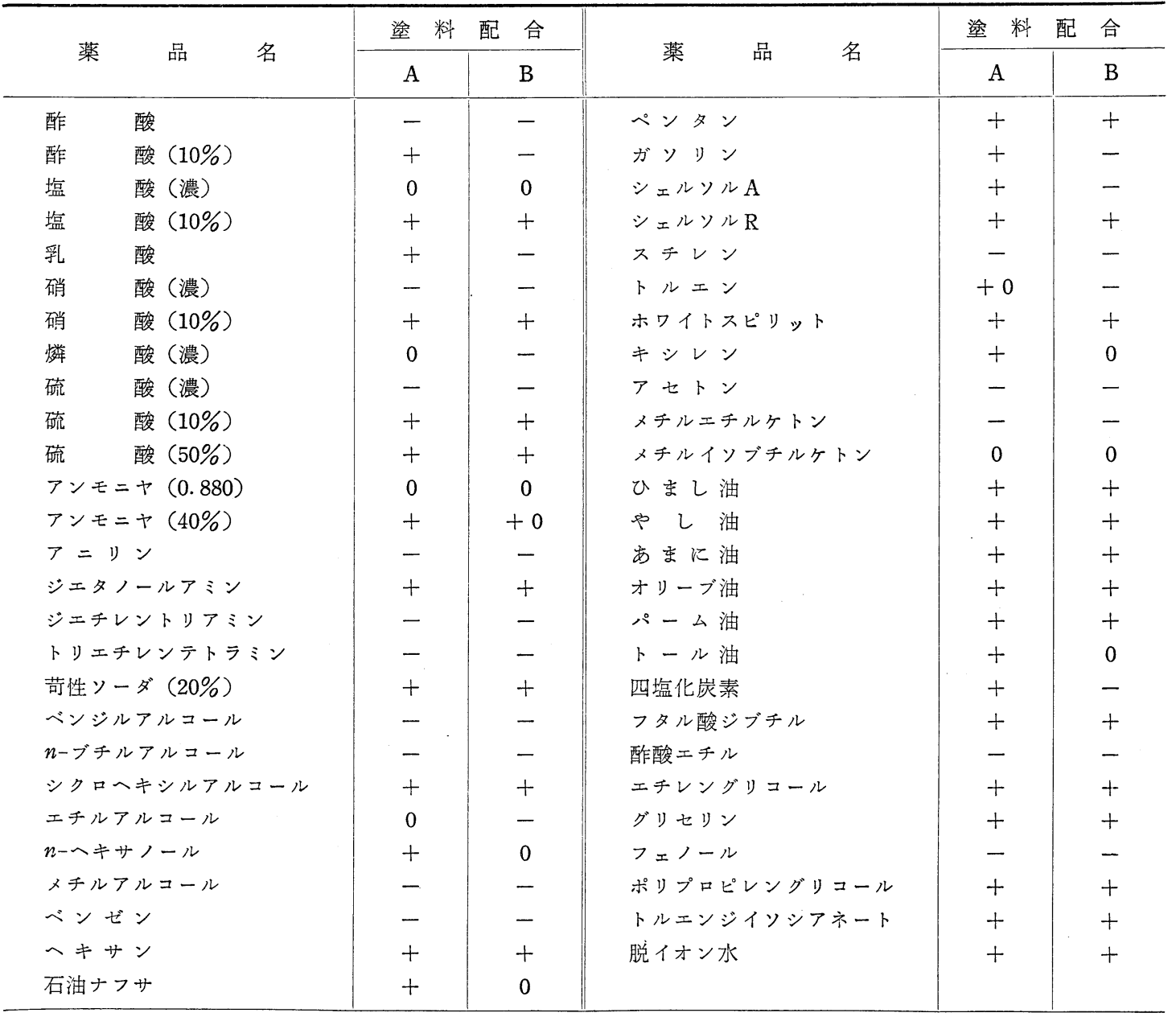

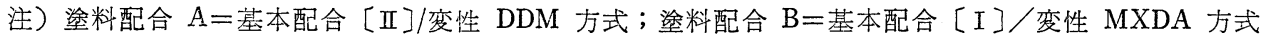
試験条件：ブラスト処理鋼板, 乾燥膜厚約 $200 \mu ; 14$ 日 $/ 23^{\circ} \mathrm{C}$ 硬化; 常温 12 カ月浸セキ

表-5 無溶剂型塗料の層間付着性

\begin{tabular}{|c|c|c|c|c|c|c|}
\hline プライマーの PVC (\%) & 25 & 30 & 35 & 40 & 45 & プライマー無し \\
\hline 引張り強さ, $\mathrm{kg} / \mathrm{cm}^{2}$ & 36 & 25 & 19 & 20 & 5 & 70 \\
\hline 破 損 の 種 類 & $\begin{array}{l}90 \% \mathrm{~A} / \mathrm{T} \\
10 \% \mathrm{P} / \mathrm{T}\end{array}$ & $\begin{array}{l}50 \% \mathrm{~A} / \mathrm{T} \\
50 \% \mathrm{P} / \mathrm{T}\end{array}$ & $10 \% \mathrm{P} / \mathrm{T}$ & $100 \% \mathrm{P}$ & $100 \% \mathrm{P}$ & 接着剽層破損 \\
\hline
\end{tabular}

注） $\mathrm{A} / \mathrm{T}=$ 接着剤/トップコート間破損， $\mathrm{P} / \mathrm{T}=$ プライマー/トップニート間破損， $\mathrm{P}=$ プライマー層内部破損 プライマーの種類；溶㣂型エポキシ系プライマー（膜厚 : $20 \sim 25 \mu$, 硬化 : 7 日 $/ 23^{\circ} \mathrm{C}$ ), 無溶剤型塗料; 基本 配合 [II]/変性 DDM 方式，(膜厚；300 350 $\mu$ ，硬化； 7 日 $/ 23^{\circ} \mathrm{C}$ )，試験条件；金属棒 $(30 \mathrm{~mm} \phi \times 76 \mathrm{~mm}$ ) をエポキシ系接着剤で塗面に接着，インストロン型引張試験機（クロスヘッドスピード； $5 \mathrm{~mm} /$ 分）で引張 り破損状態を観察

\section{4. タールエポキシ代替無溶剤型配合}

エポキシ樹脂にコールタールを配合した，いかゆる，
タールエポキシ系塗料は，良好な付着性，可撓性，耐水 性などの塗膜性能上の理由により，また経済的な優位性 により，現在でも一般防蝕塗料として広く使用され，無 
表-6 無溶㓮型とハイソリッド型との耐薬品性比較

\begin{tabular}{|c|c|c|c|c|c|c|c|c|c|c|}
\hline \multirow{3}{*}{ 試 } & \multirow{3}{*}{ 験 } & \multirow{3}{*}{ 液 } & \multicolumn{4}{|c|}{ 無 溶 凨 型 塗 料 } & \multicolumn{4}{|c|}{ ハイソリッド型塗料 } \\
\hline & & & \multicolumn{2}{|c|}{$23^{\circ} \mathrm{C} 7$ 日間硬化 } & \multicolumn{2}{|c|}{$0^{\circ} \mathrm{C} 7$ 日間硬化 } & \multicolumn{2}{|c|}{$23^{\circ} \mathrm{C} 7$ 日間硬化 } & \multicolumn{2}{|c|}{$0^{\circ} \mathrm{C} 7$ 日間硬化 } \\
\hline & & & 刷毛塗り & 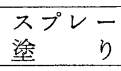 & 刷毛塗り & $\begin{array}{l}\text { スプレー } \\
\text { 㬁 }\end{array}$ & 刷毛塗り & 塗プレ & 刷毛塗り & $\begin{array}{l}\text { 塗プレー } \\
\end{array}$ \\
\hline 蒸 & 留 & 水 & O. K. & - & O. K. & - & O. K. & O. K. & O. K. & O. K. \\
\hline 酢 & & $(5 \%)$ & O. K. & - & O. K. & - & $4 \mathrm{MD}$ & $4 \mathrm{D}$ & $4 \mathrm{MD}$ & $2 \mathrm{D}$ \\
\hline 苛性 & -8 & $(5 \%)$ & O. K. & - & O. K. & - & $4 \mathrm{M}$ & O. K. & $4 \mathrm{~F}$ & O. K. \\
\hline
\end{tabular}

注） 4 カ月浸セキ/膜厚 $200 \mu$

表-7 白色エクステンダー配合系の㳂膜特性

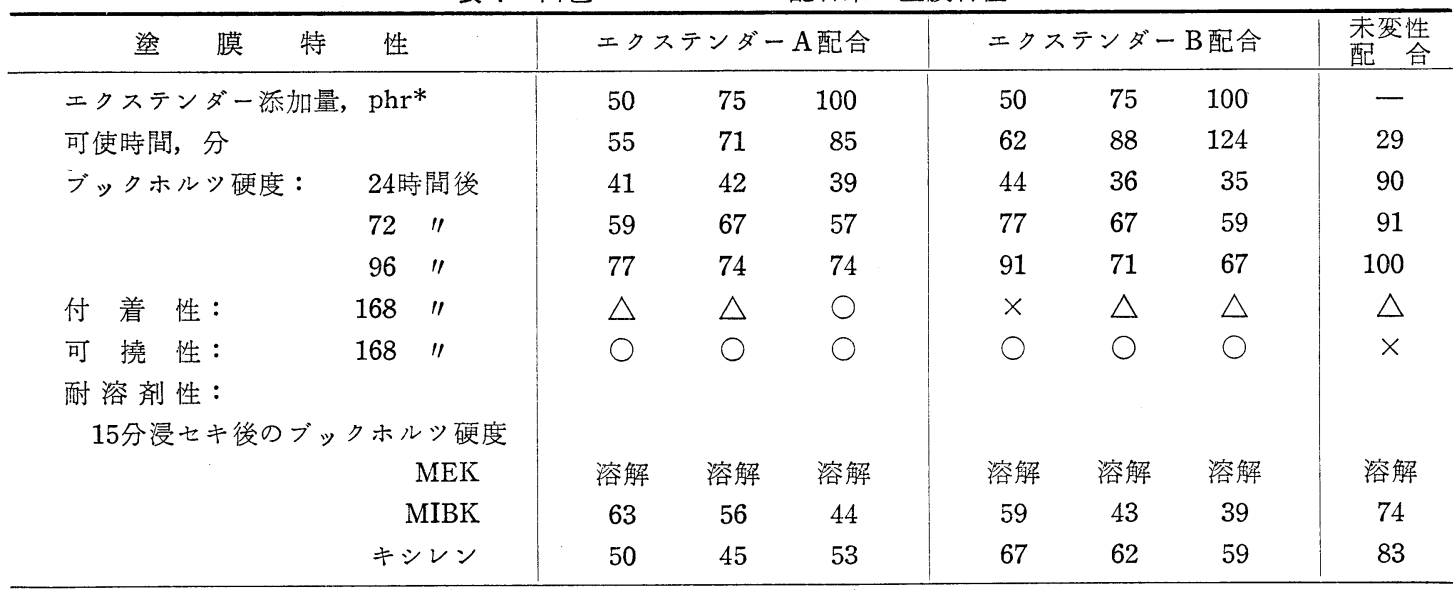

注）未変性ビス $\mathrm{A}$ 型樹脂（WPE $=180 \sim 200 ） 100$ 重量部に対する添加量/硬化剤は変性 $\mathrm{DDM}$ 使用，脱脂鋼板に 膜厚約 $500 \mu$ 飞塗布, 常温で 7 日間硬化後試験

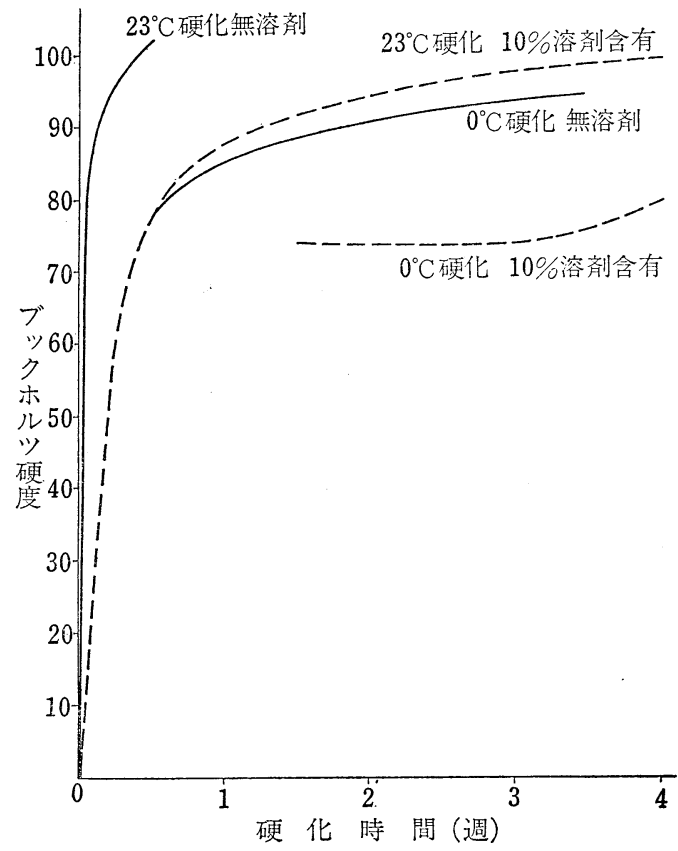

図-1 硬化時間と塗膜硬度 (膜厚 $200 \mu$ )
溶剤型のタールエポキシ塗料配合も確立している。しか し, “黑もの”という配合技術上の制約に加えて, タール 成分の有害性による取扱い規制が打出され, タール代替 可能な白色エクステンダー (増量希瀵剂) の開発が進め られてきた。

無溶剤型塗料に使用可能な白色エクステンダーとして は, 2.3 項に記した液状クマロンインデン系ポリマーや 各種の石油樹脂がある。これらエクステンダーの選択に 際しては, コールタールの場合と同様, 次の諸点を考慮 しなければならない。

1）エポキシ樹脂との相溶性

2）エポキシ樹脂／硬化剤との反応性

3）硬化速度に及ぼす影響

4) 硬化塗膜中での相溶性

5) 塗重社性

白色エクステンダーとして, 市販のクマロンインデン 系ポリマー 2 種を使用した無溶剤型クリヤー塗膜の性能 を表-7 に示した。表からわかるように，この配合系の塗 膜は，付着性が相当良好であり，可撓性も十分そなえて 
いる。また，耐溶剤性もタール配合系と同等のレベルに あると考えられる。

\section{5. 耐候性のあるハイソリッド型配合}

前項までは，主としてビス A 型樹脂を用いた配合系に ついて述べてきたが，本項では，最近米国で話題になっ ている水添ビスフェノール A 型エポキシ樹脂（以下水添 ビス $\mathrm{A}$ 型樹脂と略す）と，そのハイソリッド型塗料への 応用の可能性について述べる。

ビス $\mathrm{A}$ 型樹脂の 最大の 欠点は屋外暴露性の 覀さにあ る。この久点を改良するために，別骨格のエポキシ樹脂 がいくつか開発されてはいるが，いずれも塗料用バイン ダーとしては一長一短があり，実用化をみていない。

水添ビス $\mathrm{A}$ 型樹脂は，エポキシ樹脂特有の塗膜物性を 保持しながら，在来のビス $\mathrm{A}$ 型樹脂には見られないすぐ 机た耐候性をもち，さらに，低粘度 $(20 \sim 25$ ポイズ)で あるといら利点をもっている。この水添ビス $\mathrm{A}$ 型樹脂を 用いた配合系の塗膜物性扣よび促進暴露試験による光沢 保持性は表-8 および図-2 のとおりである。この試験配 合は八イソリッド型ではないが，塗膜物性を比較する上 で一応の目安になろう。これらのデータが示すように，

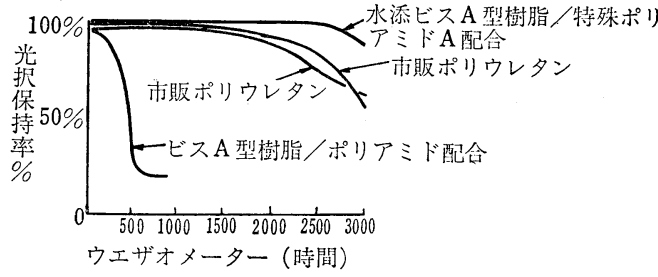

図-2 水添ビス $\mathrm{A}$ 型樹脂の光沢保持性 性能的には脂肪族ポリウレタンに類似しているが，配合 技術的にみると溶剂の幅広な選択が可能，ハイソリッド 化が容易などの面で, アクリル系, ポリウレタン系など と比較して優位性がある。水添ビス A 型樹脂の欠点とし て指摘されている点は,

1）硬化剂に選択性があり，良好な耐候性塗膜を得る には，特定の硬化剂を使用しなければならない。

2） 2 液（樹脂打よび硬化剤成分）混合後, 最低 1 時 間の熟成時間を拈いて塗装しないと，最適の塗膜物性， 光沢保持性が得られない。

しかし，この種の問題点は，今後，配合研究が進むに つれて解決されるものと考兄られる。現在, 固形分約 85\% (重量)のハイソリッド型配合を用いて，上塗り塗

表-8 水添ビス $\mathrm{A}$ 型樹脂の塗膜性能

\begin{tabular}{|c|c|c|c|c|}
\hline \multirow{2}{*}{ 性 } & \multicolumn{2}{|c|}{ 水添ビス $\mathrm{A}$ 型エポキシ } & \multicolumn{2}{|c|}{ 市販ポリウレタン } \\
\hline & $\begin{array}{c}\text { 特殊ポリアミド } \\
\text { A 配 合 }\end{array}$ & $\begin{array}{c}\text { 特殊ポリアミド } \\
\text { B 配 合 }\end{array}$ & No. 1 & No. 2 \\
\hline \multicolumn{5}{|l|}{ スプレー粘度 } \\
\hline フォードカップ No.4, 秒 & 24.0 & 22.2 & 26.7 & 31.2 \\
\hline 塗装時の固形分，\%vol. & 52.5 & 49.9 & 46.5 & 38 \\
\hline 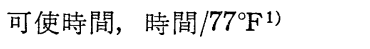 & $3 \sim 4$ & $>7$ & $>7$ & 5 \\
\hline \multicolumn{5}{|l|}{ 硬化特性， $77^{\circ} \mathrm{F}$} \\
\hline タックフリー, 時間 & $>7$ & $>7$ & $>7$ & 5 \\
\hline 24時間後の硬度 & H B & $\mathrm{B}$ & $\mathrm{F}$ & B \\
\hline 耐溶剂性 ${ }^{2)}$, 分 & 40 & $2 \sim 4$ & 10 & 30 \\
\hline 鉛 筆 硬 度 & $2 \mathrm{H}$ & $2 \mathrm{H}$ & $>7 \mathrm{H}$ & $2 \mathrm{H}$ \\
\hline \multicolumn{5}{|l|}{ 耐 衝 撃 性 } \\
\hline 直接, インチ・ポンド & 62 & 56 & 26 & 46 \\
\hline 裏面, インチ・ポンド & 16 & 16 & $>4$ & 20 \\
\hline コニカルマンドレル, インチ & $1 / 8$ & $1 / 8$ & $1 / 8$ & $1 / 8$ \\
\hline \multirow{2}{*}{\multicolumn{5}{|c|}{$\begin{array}{l}\text { 密着性，クロスハッチ } \\
\text { 未処理鋼板 }\end{array}$}} \\
\hline & 10 & 10 & 10 & 10 \\
\hline & 10 & 10 & 10 & 10 \\
\hline 光 沢 & & & & \\
\hline $60^{\circ}$ & 94 & 95 & 97 & 88 \\
\hline $30^{\circ}$ & 86 & 86 & 90 & 76 \\
\hline
\end{tabular}

1）熟成後，エナメル粘度がフォードカップ No. 4 で 40 秒に達するまでに経過した時間.

2） 7 日間硬化後，MIBK に浸セキ，鉛筆硬度で 2 単位低下するまでの時間. 
料としての実用性能評価が進められている。

将来的には, 水添ビス $\mathrm{A}$ 型樹脂は在来のエポキシ系塗 料が不適とされ, 無黄変ポリウレタン, アクリル系塗料 等が採用されてきた分野, すなわち, 耐候性と強靭性が 要求される用途に拈いて, ハイソリッド型の上塗り塗料 用バインダーとして有用視されるであろう。

\section{6. おわりに}

エポキシ樹脂を用いた常温乾燥形 2 液性の無溶剂型, およびハイソリッド型塗料は古くから知られているが, 今な㸱，未解決の問題点を残している。2 液混合時の反 応はなるべく遅く, 塗装後はすみやかに硬化乾燥する塗 料が理想であるが，この 2 点は配合技術的に背反する性 質であり，1つの配合で解決されるものではない。2液 式ホットスプレー装置の使用により，この難問は解消す るが，この種の装置は高価なためなかなか 普及を見な い。無溶剤型, およびハイソリッド型塗料の研究開発
は, 塗膜性能と塗装作業性のバランス追求というシーソ ーゲーム的な側面をもっており，よりバランスのとれた 塗料配合の開発には, 樹脂, 硬化剤, 希釈剤などを含め た総合的な研究アプローチが要求される。

本稿により, 無溶剤型, あるいはハイソリッド型エポ キシ樹脂塗料の問題点の所在をは握され, 今後の研究に 役立てて頂ければ幸いである。なお，焼付塗料の分野に おいても, エポキシ系の無溶剤型, あるいはハイソリッ ド型塗料に関し多くの研究がなされているが，これにつ いては他の機会に譲ることにした。ご了承いただきた wo

\section{参考資料}

1）油化シェル：塗料技術ニュース（No.135，140, 75 p. : 2 など)

2) Shell : Technical Bulletin (EP 2.6)

3) R.S. Bauer : Water-Borne and Higher Solids Coatings Symposium, 1979 Feb. 148 182. 